\title{
A convenient and reproducible method to genetically transform bacteria of the genus Bifidobacterium
}

\author{
Alessandra Argnani, $\uparrow$ Rob J. Leer, Nicole van Luijk and Peter H. Pouwels
}

Author for correspondence: Peter H. Pouwels. Tel: +31 1528431 76. Fax: +31 152843989.

e-mail: Pouwels@voeding.tno.nl

TNO Nutrition and Food Research Institute, Department of Molecular Genetics and Gene Technology, PO Box 5815 2280 HV Rijswijk, The Netherlands

\begin{abstract}
A protocol was developed for the introduction of foreign plasmid DNA into various Bifidobacterium strains. The method, which is applicable to all Bifidobacterium species tested so far, is based on electroporation of bacteria made competent by preincubation in electroporation buffer for several hours at $4{ }^{\circ} \mathrm{C}$. Transformation of Bifidobacterium could be achieved with a plasmid vector originating from Bifidobacterium and with plasmid vectors from Corynebacterium, but not with vectors carrying replicons from Lactococcus or Lactobacillus.
\end{abstract}

Keywords: Bifidobacterium, electrotransformation, plasmid vector

\section{INTRODUCTION}

Bifidobacteria are Gram-positive, anaerobic, catalasenegative, fermentative rods, which are often $\mathrm{Y}$ - or $\mathrm{V}$ shaped. Although there has been much confusion over the years as to the classification of this type of bacteria, there is now general agreement among taxonomists that bifidobacteria should be classified in the genus Bifidobacterium, which is now included in the family Actinomycetaceae. Bifidobacteria belong to a subclass of the Gram-positive bacteria, the genome of which is very GC-rich. Other genera of this group include Mycobacterium, Corynebacterium and Streptomyces. The GC content of bifidobacteria is between 55 and $64 \mathrm{~mol} \%$ (Scardovi, 1986).

Bifidobacteria are among the most abundant species in the lower small intestine of man and animals. The distal ileum may contain $10^{5}-10^{7}$ organisms per $\mathrm{ml}$ of intestinal content (Gorbach et al., 1967; Drasar et al., 1969). Bifidobacteria are also prominent in the human large intestine and are present at concentrations of $10^{\mathbf{1 0}}$ or more per g gut content, constituting 5-10\% of total flora in the bowel (Mitsuoka, 1992).

It is widely believed that bifidobacteria have beneficial properties for their host, but convincing scientific data supporting this are scarce. Besides the assumed healthpromoting properties of some Bifidobacterium species for humans, the economic importance of these microorganisms is beyond doubt. Bifidobacterium strains are

†Present address: Istituto di Cancerologica, Università di Bologna, Bologna, Italy. widely used for the preparation of fermented milk products in many Asiatic and Western countries. To be able to fully exploit the potential of these organisms for practical application, detailed knowledge is required about such basic biological phenomena as cellular metabolism, gene expression, protein secretion, etc. However, studies on Bifidobacterium at the molecular level would be severely limited in the absence of an efficient transformation system. The availability of a system for genetic transformation would also enable strain improvement programmes to be carried out.

Although the electroporation technique has proven to be widely applicable to genetically transform bacterial strains from several genera of lactic acid bacteria, like Lactococcus, Pediococcus, Lactobacillus, Enterococcus (Harlander, 1987; Chassy \& Flickinger, 1987; Luchansky et al., 1988; Holo \& Nes, 1989; Cruz Rodz \& Gilmore, 1990; Posno et al., 1991), and corynebacteria and brevibacteria (Chassy et al., 1988; Bonnassie et al., 1990), all Bifidobacterium strains so far examined have proved refractory to efficient and reproducible transformation. In this paper we describe the development of a system for efficient and reproducible genetic transformation of strains of the genus Bifidobacterium. The system is based on preincubation of the bacteria at low temperatures in electroporation buffer prior to electroporation, and on the use of plasmid vectors with a replicon from Actinomycetaceae.

\section{METHODS}

Bacterial strains and plasmids. The Bifidobacterium strains used were: B. animalis ATCC 27536, B. bifidum ATCC 15696 and B. infantis ATCC 27920 (American Type Culture Collection); B. 
Table 1. Plasmids

\begin{tabular}{|c|c|c|c|}
\hline Plasmid & Markers & Size (kb) & Reference \\
\hline pGK12 & $\mathrm{Em}^{\mathrm{r}} \mathrm{Cm}^{\mathrm{r}}$ & $4 \cdot 4$ & Kok et al. (1984) \\
\hline pLP825 & $A m p^{r} \mathrm{Cm}^{r}$ & $7 \cdot 7$ & Posno et al. (1991) \\
\hline pDG7 & $A m p^{r} \mathrm{Cm}^{r}$ & $7 \cdot 3$ & $\begin{array}{l}\text { Matteuzzi et al. } \\
(1990)\end{array}$ \\
\hline pEBM3 & $\mathrm{Km}^{\mathrm{r}} \mathrm{Cm}^{\mathrm{r}}$ & $9 \cdot 6$ & $\begin{array}{l}\text { Gift from J. } \\
\text { Kalinowski }\end{array}$ \\
\hline pECM2 & $\mathrm{Km}^{\mathrm{r}} \mathrm{Cm}^{\mathrm{r}}$ & $10 \cdot 3$ & $\begin{array}{l}\text { Gift from J. } \\
\text { Kalinowski }\end{array}$ \\
\hline
\end{tabular}

breve 4 (laboratory collection); B. breve AS (gift from C. Romond (University of Lille); and B. bifidum U3, B. infantis U1, $B$. longum $\mathrm{U} 2$ and $B$. longum Wiesby 2 (gifts from Unilever, Vlaardingen, the Netherlands). None of these Bifidobacterium strains carries a plasmid. The plasmids used are listed in Table 1. Plasmid pDG7, obtained from Dr D. Matteuzzi and described in Matteuzzi et al. (1990), is an Escherichia coli-Bifidobacterium shuttle vector based on a small cryptic plasmid from B. longum B2577 (Sgorbati et al., 1982) and pJH101. Plasmids pEBM3 and pECM2, obtained from Dr J. Kalinowski, are E. coliCorynebacterium shuttle vectors. Plasmid pLP825, described in Posno et al. (1991), is an E. coli-Lactobacillus shuttle vector capable of replication in various lactobacilli, and plasmid pGK12, described by Kok et al. (1984), is a broad-host-range vector that replicates in various Gram-positive and Gramnegative bacteria. All vectors contain the chloramphenicol resistance gene from $\mathrm{pC194}$, which was used for selection in bifidobacteria.

Preparation of plasmid DNA. Plasmid DNA was isolated using a QIAGEN Plasmid Mini Kit according to a protocol supplied by the manufacturer. It was modified for Bifidobacterium by addition of lysozyme (Boehringer) to the resuspension buffer ( $30 \mathrm{mg}$ per $\mathrm{ml}$ buffer) and incubation at $37^{\circ} \mathrm{C}$ for $40 \mathrm{~min}$. Smallscale isolation of plasmid DNA was performed following the protocol described in Sambrook et al. (1989), modified for Bifidobacterium by using lysozyme at $30 \mathrm{mg} \mathrm{m}^{-1}$ instead of $5 \mathrm{mg}$ $\mathrm{ml}^{-1}$, and incubating at $37^{\circ} \mathrm{C}$ for $40 \mathrm{~min}$.

Media and growth conditions. E. coli strain DH5 $\alpha$, used as host strain for propagating the shuttle vectors, was cultivated in L-medium (Sambrook et al., 1989) supplemented with the appropriate antibiotic: kanamycin (Sigma), final concentration $50 \mu \mathrm{g} \mathrm{ml}^{-1}$, and ampicillin (Sigma), final concentration $50 \mu \mathrm{g}$ $\mathrm{ml}^{-1}$. Bifidobacteria were routinely cultivated in MRS broth (Difco) supplemented with $0.05 \%$ (final concentration) cysteine. $\mathrm{HCl}$ at $37^{\circ} \mathrm{C}$; for some of the Bifidobacterium strains anaerobiosis was essential for growth.

Preparation of bacteria for electroporation. An overnight culture of Bifidobacterium was used to inoculate fresh MRS broth supplemented with $0.05 \%$ (final concentration) cysteine. $\mathrm{HCl}$ and $0.5 \mathrm{M}$ (final concentration) sucrose (Merck) and cultivated overnight at $37^{\circ} \mathrm{C}$ (some strains anaerobically). This overnight culture was diluted $1: 25$ in fresh MRS broth supplemented with $0.05 \%$ cysteine and $0.5 \mathrm{M}$ sucrose and cultivated at $37{ }^{\circ} \mathrm{C}$ until an $\mathrm{OD}_{695}$ of $\sim 0.2$ was reached. Bacteria were chilled on ice, harvested by centrifugation and washed twice with $0.5 \mathrm{M}$ sucrose. Finally, they were resuspended in about $1 / 250$ of the original culture volume of ice-cold $0.5 \mathrm{M}$ buffered sucrose, dispensed in Eppendorf tubes and incubated at $0-37^{\circ} \mathrm{C}$ for $0-25 \mathrm{~h}$.
Electroporation. Plasmid DNA $(0 \cdot 5-1 \cdot 5 \mu \mathrm{g})$ was mixed with $80 \mu \mathrm{l}$ bacterial suspension in a pre-cooled Gene Pulser disposable cuvette (inter-electrode distance $0.2 \mathrm{~cm} ; \mathrm{Bio}-\mathrm{Rad}$ ). A highvoltage electric pulse was delivered with a Gene Pulser apparatus (Bio- $\mathrm{Rad}$ ) by using the $25 \mu \mathrm{F}$ capacitor and setting the pulse controller at $200 \Omega$ parallel resistance, yielding a pulse duration of 3-4.6 ms. Following electroporation, bacteria were diluted with $800 \mu \mathrm{l}$ MRS broth supplemented with $0.05 \%$ cysteine and $0.5 \mathrm{M}$ sucrose. The bacteria were incubated for about $2.5 \mathrm{~h}$ at $37^{\circ} \mathrm{C}$ to allow for recovery and expression of the antibiotic resistance marker and, finally, plated on MRS agar $(1.5 \%, \mathrm{w} / \mathrm{v})$ supplemented with $0.05 \%$ cysteine, $0.5 \mathrm{M}$ sucrose and $10 \mu \mathrm{g}$ chloramphenicol $\mathrm{ml}^{-1}$ (final concentration; Boehringer). Plates were incubated anaerobically at $37^{\circ} \mathrm{C}$ for 2 or $3 \mathrm{~d}$, after which small-size or full-size colonies, respectively, were visible.

\section{RESULTS AND DISCUSSION}

The main purpose of this work was to develop a method that would allow transformation of Bifidobacterium. Initially, various protocols used for transformation by electroporation of other micro-organisms were tried, but without any success.

\section{Preparation of recipient bacteria for electroporation}

Bifidobacteria have a very thick and complex cell wall (Fischer, 1987). The presence of a thick (multi-layered) cell wall generally forms a barrier for the uptake of exogenous DNA molecules. This conclusion was inferred from experiments in which the efficiency of transformation of different strains of Listeria monocytogenes and that of corynebacteria was improved by treatment of the cells with penicillin $\mathrm{G}$, glycine and D-amino acids, or muralytic enzymes (Powell et al., 1988; Bonnassie et al., 1990; Park \& Stewart, 1990; Dunny et al., 1991). An attempt was made to modify the structure of the cell wall by preincubation of the bacteria in electroporation buffer. The occurrence of electrotransformation-competent Lactobacillus bulgaricus bacteria by pretreatment in a buffer of high ionic strength has been attributed to limited autolysis (Sasaki et al., 1987). Electrotransformationcompetent bifidobacteria were obtained by cultivating the bacteria in MRS broth supplemented with $0.5 \mathrm{M}$ sucrose, washing them in buffered sucrose as described in Methods, and storing them in the electroporation buffer at $4{ }^{\circ} \mathrm{C}$. Bifidobacterium cells obtained with this treatment are completely viable and show no morphological changes. In preliminary experiments in which pretreated $B$. animalis was transformed with pDG7 in an electroporation buffer composed of $0.5 \mathrm{M}$ sucrose $+1 \mathrm{mM}$ ammonium citrate, $\mathrm{pH} 6$, several hundred chloramphenicol-resistant colonies were found on selective plates.

To determine whether the composition of the electroporation buffer would affect the transformation efficiency, six different buffers were utilized (Table 2). A buffer containing $1 \mathrm{mM}$ ammonium citrate, $\mathrm{pH} \mathrm{6}$, gave the highest number of transformants. The presence of a high concentration of sucrose in the growth medium and electroporation buffer proved to be essential, as no transformants were observed when bacteria were cul- 
Table 2. Effect of electroporation buffer composition on transformation efficiency of B. animalis ATCC 27536

The suspension buffer contained $0.5 \mathrm{M}$ sucrose and the concentration of buffer was $1 \mathrm{mM}$. Pretreatment was for $14 \mathrm{~h}$ at $4{ }^{\circ} \mathrm{C}$. The voltage used for electroporation was as indicated and the resistance was set at $200 \Omega$.

\begin{tabular}{|c|c|c|}
\hline \multirow[t]{2}{*}{ Buffer } & \multicolumn{2}{|c|}{$\begin{array}{c}\text { Transformants per } \\
\mu \mathrm{g} \text { pDG7 DNA }\end{array}$} \\
\hline & 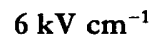 & $10 \mathrm{kV} \mathrm{cm}-1$ \\
\hline Citrate, $\mathrm{pH} 5$ & 65 & 740 \\
\hline Citrate, $\mathrm{pH} 6$ & 130 & 2700 \\
\hline Phosphate, $\mathrm{pH} 4.5$ & 200 & 940 \\
\hline Phosphate, $\mathrm{pH} 6$ & 20 & 500 \\
\hline HEPES, pH 6 & 20 & 1700 \\
\hline HEPES, $\mathrm{pH} 7 \cdot 4$ & 0 & 660 \\
\hline
\end{tabular}

tivated in the absence of the osmotic stabilizer, or when the electroporation buffer contained no sucrose. An electric pulse of $10 \mathrm{kV} \mathrm{cm}^{-1}$ yielded a higher number of transformants than a pulse of $6 \mathrm{kV} \mathrm{cm}{ }^{-1}$, irrespective of the buffer used.

To confirm that the antibiotic-resistant colonies were truly Bifidobacterium transformants, plasmid DNA was isolated and analysed by gel electrophoresis. As shown in Fig. 1, all chloramphenicol-resistant colonies tested contained a plasmid indistinguishable in size from the parent plasmid, pDG7. In addition, when plasmid DNA isolated from transformed cells was used to transform E. coli, transformants were obtained containing a plasmid with the same restriction enzyme profile as that of pDG7. Finally, the sugar metabolism profile of the transformants, analysed with an API test system, was the same as that of the untransformed Bifidobacterium strains (results not shown).

Since this work was completed, Missich et al. (1994) have reported low-efficiency transformation by electroporation of a strain of $B$. longum using a plasmid vector from $B$. longum B2577 with properties similar to those of pDG7. The procedure described involves freezing of the bacteria at $-135^{\circ} \mathrm{C}$ for $1 \mathrm{~h}$ in sterile glycerol and storage at $-70^{\circ} \mathrm{C}$, prior to electroporation. We assume that freezing and thawing of bacteria mimics limited autolysis, which could explain the transformation of this bifidobacterial strain, although with low efficiency.

\section{Electroporation conditions}

Fig. 2 shows the effect of variation of the applied voltage on the transformation efficiency of $B$. animalis. Optimal results were obtained when the voltage applied to the cuvette was $12 \mathrm{kV} \mathrm{cm}^{-1}$ and the resistance was set at $200 \Omega$. When the resistance was set at $100 \Omega$, the time constant obtained during electroporation was lower, resulting in a lower number of transformants. At $400 \Omega$, the viability of the bacteria was reduced, resulting in a decrease of the number of transformants (data not shown). For optimal results (with a time constant between 4 and 4.5) the volume of buffer in which the cells are resuspended after the washing steps should be about 2-3 times the volume of bacteria. A higher cell concentration lowers the transformation efficiency. In all other experiments with pDG7 DNA a voltage of $12 \mathrm{kV} \mathrm{cm}$ chas $^{-1}$ was applied at a resistance of $200 \Omega$.

\section{Optimization of transformation of B. animalis}

The effect of the duration and temperature of the preincubation step on the transformation efficiency of $B$. animalis is shown in Fig. 3. The highest transformation efficiency $\left(9.4 \times 10^{4}\right)$ was found after incubation of the bacteria at $4{ }^{\circ} \mathrm{C}$ for $3.5 \mathrm{~h}$. Incubation at lower or higher temperatures resulted in a reduction of the transformation efficiency. At temperatures over $14{ }^{\circ} \mathrm{C}$ the transformation efficiencies decreased rapidly. When the preincubation step was carried out at $37^{\circ} \mathrm{C}$ essentially the same results were obtained as at $25^{\circ} \mathrm{C}$ (not shown).

\section{Transformation of different Bifidobacterium strains}

Application of the pretreatment and electroporation procedure described above for $B$. animalis (pretreatment overnight at $4{ }^{\circ} \mathrm{C}$ in $1 \mathrm{mM}$ citrate buffer, $\mathrm{pH} \mathrm{6}$; pulse $12 \mathrm{kV} \mathrm{cm}^{-1}$ at $200 \Omega$ ) to other Bifidobacterium species and strains yielded many transformants (Table 3). Although the efficiencies varied from strain to strain, several strains could be reproducibly transformed with high efficiency (up to $7 \times 10^{4}$ per $\mu \mathrm{g}$ pDG7 DNA). Differences in transformation efficiency were observed after overnight pretreatment depending on the purity of the DNA preparations used for transformation. For example, $B$. animalis ATCC 27536 reproducibly yielded $8 \times 10^{4}$ transformants per $\mu \mathrm{g}$ DNA with a newly isolated preparation of pDG7 DNA. No attempts have been made thus far to optimize the transformation efficiencies for strains other than B. animalis ATCC 27536.

\section{Transformation of Bifidobacterium with vectors from Corynebacterium}

Since from a phylogenetic point of view Corynebacterium spp. are related to Bifidobacterium, we investigated the ability of two plasmids with a Corynebacterium replicon (pEBM3 and pECM2) to transform B. animalis. Both plasmids yielded transformants containing a plasmid with a structure indistinguishable by restriction enzyme analysis from that of the parent plasmid (not shown). Approximately $2 \times 10^{3}$ transformants were obtained per $\mu \mathrm{g}$ DNA, after overnight pretreatment of bacteria at $4^{\circ} \mathrm{C}$ in $1 \mathrm{mM}$ citrate buffer, $\mathrm{pH} 6,+0.5 \mathrm{M}$ sucrose; electroporation $10 \mathrm{kV} \mathrm{cm}{ }^{-1}$. These results clearly demonstrate that Corynebacterium plasmids can replicate in $B$. animalis. Since the intensity of the plasmid band visualized by staining of the gel after electrophoresis of miniscreen DNA was comparable to that of $\mathrm{pDG} 7$ in Bifidobacterium transformants, the copy numbers of the Corynebacterium vectors 


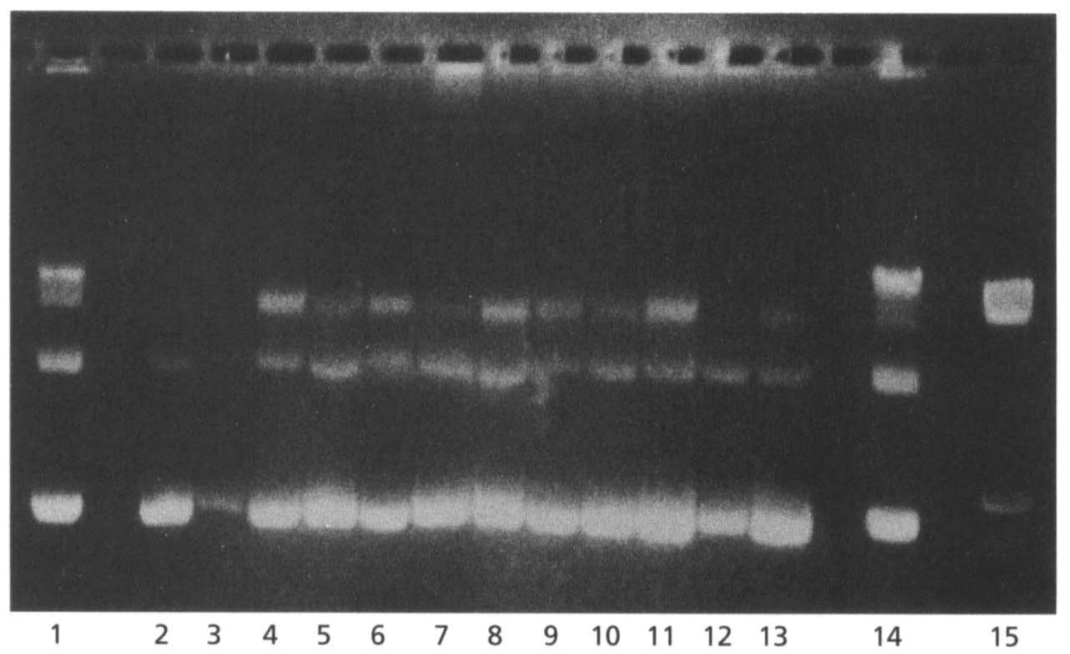

Fig. 1. Agarose gel electrophoresis of plasmid DNA extracted from transformants compared with plasmid pDG7 from $E$. coli used for transformation. Lanes: 1 and 14, $0.5 \mu \mathrm{g} \mathrm{pDG7}$ (control) isolated from E. coli; 2 and 3 , clones from citrate $\mathrm{pH} 5 ; 4$ and 5 , clones from citrate $\mathrm{pH} \mathrm{6;6}$ and 7 , clones from phosphate $\mathrm{pH} \mathrm{4.5;8}$ and 9 , clones from phosphate $\mathrm{pH} 6 ; 10$ and 11 , clones from HEPES pH 6; 12 and 13, clones from HEPES $\mathrm{pH} 7.4 ; 15$, lambda/EcoRI/HindIII.

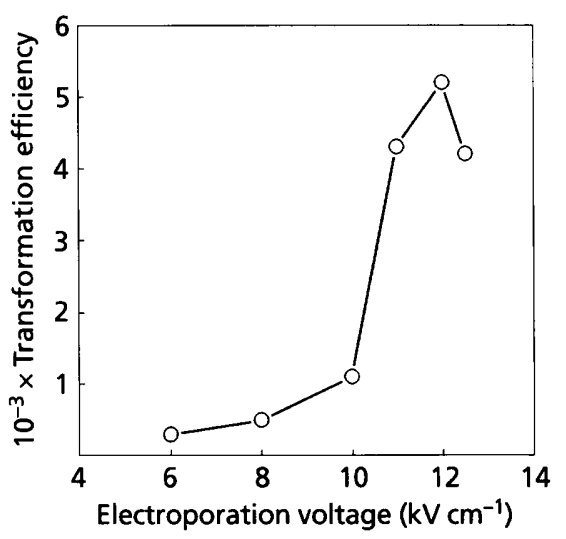

Fig. 2. Effect of voltage used for electroporation on the efficiency of transformation of $B$. animalis (expressed as the number of transformants per $\mu \mathrm{g}$ pDG7 DNA). Resistance was set at $200 \Omega$. Bacteria were incubated for $13-14 \mathrm{~h}$ at $4{ }^{\circ} \mathrm{C}$ in $0.5 \mathrm{M}$ sucrose $+1 \mathrm{mM}$ ammonium citrate, $\mathrm{pH} 6$, prior to electroporation.

do not seem to differ greatly from that of pDG7. All attempts to transform Lactobacillus case $i$ with $\mathrm{pDG} 7$ or $\mathrm{pEBM} 3 / \mathrm{pECM} 2$ have failed, suggesting that these plasmids cannot replicate in this organism. Interestingly, a plasmid from Corynebacterium dipbtheriae, pNG2, has been shown to replicate autonomously in Corynebacterium, Mycobacterium and E. coli (Messerotti et al., 1990). Our observation that the Corynebacterium plasmids pEMB3 and pECM2 replicate in B. animalis, while plasmid pNG2 can replicate in Mycobacterium, might suggest that replication functions of some plasmids from bacteria of the so-called GC-rich branch of the evolutionary tree of the bacterial kingdom are recognized in different hosts, as are replication functions of some plasmids of the AT-rich branch (Gruss \& Ehrlich, 1989; Del Solar et al., 1993). In support of this view, we have observed that the presumed replication protein of the Corynebacterium plasmid pXZ10142 (EMBL/GenBank accession number X72691) is strikingly similar to that of the Mycobacterium

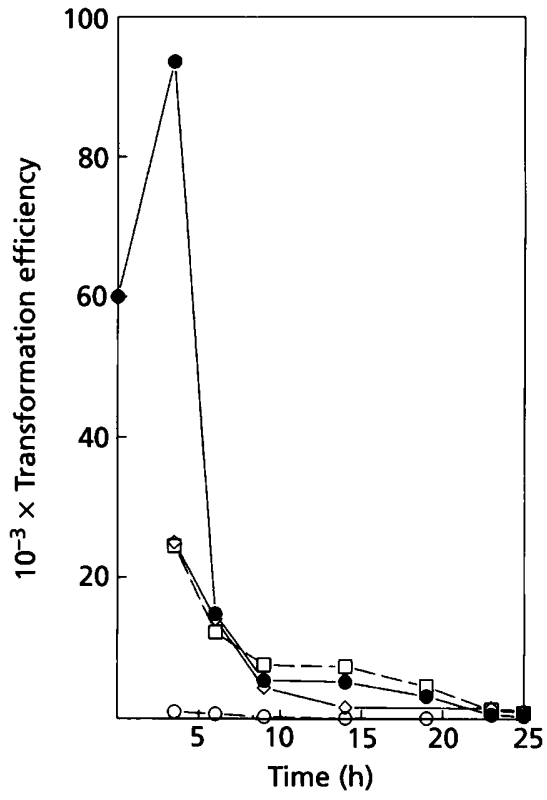

Fig. 3. Relationship between temperature and duration of incubation of bacteria in electroporation buffer and the efficiency of transformation of $B$. animalis (expressed as number of transformants per $\mu \mathrm{g}$ pDG7 DNA). The suspension buffer contained $0.5 \mathrm{M}$ sucrose $+1 \mathrm{mM}$ ammonium citrate, $\mathrm{pH} 6$. The voltage used for electroporation was $12 \mathrm{kV} \mathrm{cm}^{-1}$. Resistance was set at $200 \Omega$. Preincubation temperature: $0^{\circ} \mathrm{C}(\diamond), 4^{\circ} \mathrm{C}$ (O), $14^{\circ} \mathrm{C}(\square)$ or $25^{\circ} \mathrm{C}(\mathrm{O})$.

plasmid pAL5000 (Ranes et al., 1990) and also, but to a lesser extent, to those of plasmids ColE3 from E. coli (Yasueda et al., 1989) and pJD1 from Neisseria gonorrboeae (Korch et al., 1985; Fig. 4). The similarity of the replication protein of pXZ10142 with the other three proteins ranges from $46 \%$ to $57 \%$, but is considerably higher in the regions between amino acids 110-200, 220-237 and 251-320. These proteins show no resemblance to replication proteins of plasmids of the AT-rich branch. Nucleotide sequence analysis might reveal 
Table 3. Transformation of different bifidobacterial strains

Prior to electroporation, bacteria were incubated overnight at $4{ }^{\circ} \mathrm{C}$ in $0.5 \mathrm{M}$ sucrose $+1 \mathrm{mM}$ ammonium citrate, $\mathrm{pH}$ 6. The voltage used for electroporation was $12 \mathrm{kV} \mathrm{cm}^{-1}$ and the resistance was set at $200 \Omega$.

\begin{tabular}{|lc|}
\hline Strain & $\begin{array}{c}\text { Transformants } \\
\text { per } \boldsymbol{\mu g} \\
\text { pDG7 DNA }\end{array}$ \\
& $5 \times 10^{3}$ \\
\hline B. animalis ATCC 27536 & $1.3 \times 10^{4}$ \\
B. breve 4 & $2 \times 10^{2}$ \\
B. breve AS & $3 \times 10^{2}$ \\
B. bifidum U3 & $7 \cdot 4 \times 10^{3}$ \\
B. bifidum ATCC 15696 & $2.5 \times 10^{2}$ \\
B. infantis U1 & $4 \times 10^{4}$ \\
B. infantis ATCC 27920 & $2 \cdot 6 \times 10^{3}$ \\
B. longum U2 & $7 \times 10^{4}$ \\
B. longum Wiesby 2 & \\
\hline
\end{tabular}

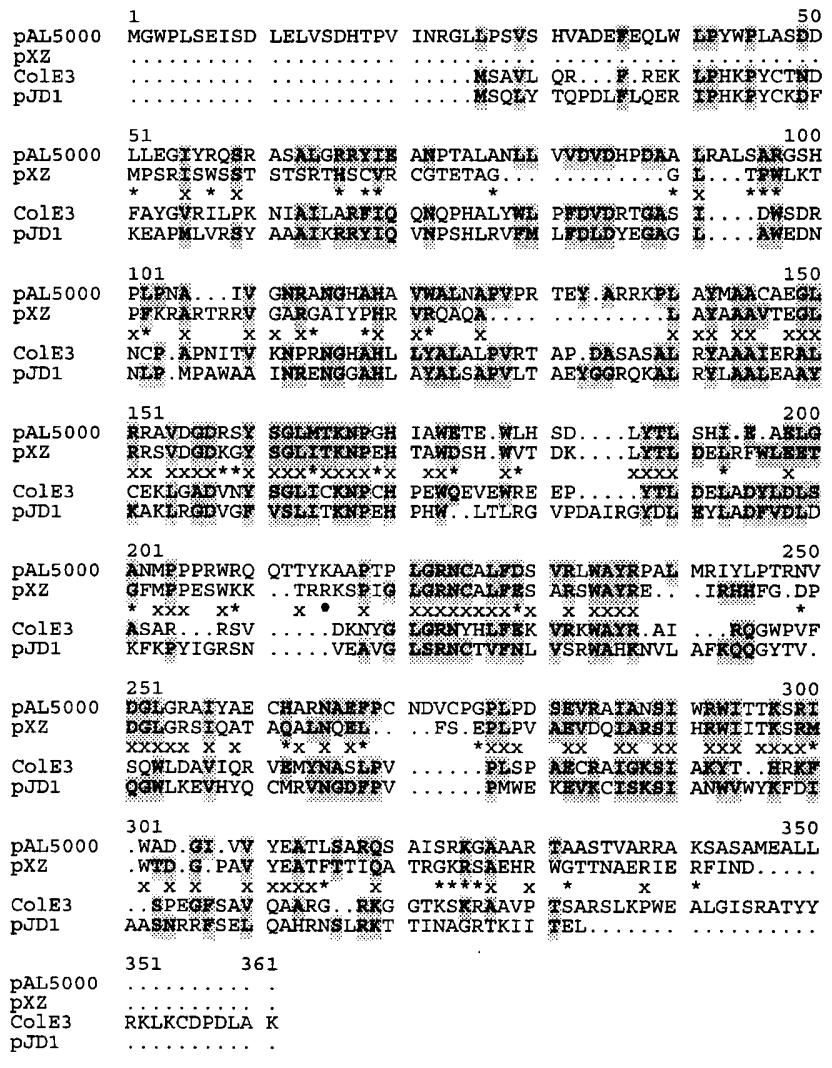

Fig. 4. Comparison of the deduced amino acid sequence of the replication protein genes of plasmids from different bacteria. The sequences were aligned with the GCG software program PileUp. Identical and similar amino acids in the proteins of pAL5000 and pXZ (pXZ10142) are indicated by $x$ and *, respectively. Regions of similarity in all four proteins are shaded. The four plasmids are described in the text. whether Bifidobacterium plasmids like pDG7 show similarity to Corynebacterium and Mycobacterium plasmids and form part of a larger plasmid family.

\section{Plasmid vectors from lactococci and lactobacilli do not replicate in Bifidobacterium}

Despite several attempts, we have been unable to transform $B$. animalis with plasmid pLP825, carrying a replicon from L. plantarum (Posno et al., 1991) or with the broadhost-range Lactococcus plasmid pGK12 (Kok et al., 1984). These two plasmids, which have a GC content of $\sim 35$ $\mathrm{mol} \%$, are typical representatives of a family of AT-rich plasmids shown before to replicate in a variety of organisms of the AT-rich branch (Gruss \& Ehrlich, 1989; Del Solar $e t$ al., 1993). In contrast to the family of AT-rich plasmids, plasmids from Bifidobacterium, Mycobacterium and Corynebacterium are GC-rich (GC content 55-65 mol\%). The inability of AT-rich plasmids like pLP825 and pGK12 to replicate in $B$. animalis, and presumably in other Bifidobacterium strains, may be explained by assuming that the AT-rich expression signals of the replication functions are not, or are inefficiently, recognized by the host enzymes.

\section{ACKNOWLEDGEMENTS}

We thank Hanny Hessing for valuable suggestions with regard to the comparison of protein sequences. Part of the results presented in this paper have been described in patent application EP 94201746.

\section{REFERENCES}

Bonnassie, S., Burini, I. T., Moglia, I., Trautwetter, A., Patte, I. C. \& Sicard, A. M. (1990). Transfer of plasmid DNA to Brevibacterium lactofermentum by electroporation. J Gen Microbiol 136, 2107-2112.

Chassy, B. M. \& Flickinger, J. L. (1987). Transformation of Lactobacillus casei by electroporation. FEMS Microbiol Lett 44, 173-177.

Chassy, B. M., Mercenier, A. \& Flickinger, J. L. (1988). Transformation of bacteria by electroporation. Trends Biotechnol 6, 303-309.

Cruz Rodz, A. L. \& Gilmore, M. S. (1990). High introduction of plasmid DNA into glycine treated Enterococcus faecalis by electroporation. Mol \& Gen Genet 224, 152-154.

Del Solar, G., Moscoso, M. \& Espinosa, M. (1993). Rolling circlereplicating plasmids from gram-positive and gram-negative bacteria: a wall falls. Mol Microbiol 8, 789-796.

Drasar, B. S., Shiner, M. \& McLeod, G. M. (1969). Studies on the intestinal flora. I. The bacterial flora of the gastrointestinal tract in healthy and achlorhydric persons. Gastroenterology 56, 71-79.

Dunny, G. M., Lee, L. N. \& LeBlanc, D. J. (1991). Improved electroporation and cloning vector system for Gram-positive bacteria. Appl Environ Microbiol 57, 1194-1201.

Fischer, W. (1987). Analysis of the lipoteichoic acid-like macroamphiphile from Bifidobacterium bifidum subspecies pennsylvanium by one- and two-dimensional $1 \mathrm{H}$ - and 13C-NMR spectroscopy. Eur J Biochem 165, 647-652.

Gorbach, S. L., Plaut, A. G., Nahas, L., Weinsrein, L., Spanknebel, I. G. \& Levitan, R. (1967). Studies in intestinal microflora. II. Microorganisms of the small intestine and their relations to oral and fecal flora. Gastroenterology 53, 856-867. 
Gruss, A. \& Ehrlich, S. D. (1989). The family of highly interrelated single-stranded deoxyribonucleic acid plasmids. Microbiol Rev 53, 231-241.

Harlander, S. (1987). Gene transfer systems in lactic streptococci. In Streptococcal Genetics, pp. 229-233. Edited by J. J. Ferretti \& R. C. Curtiss. Washington, DC: American Society for Microbiology.

Holo, H. \& Nes, I. F. (1989). High frequency transformation by electroporation of Lactococcus lactis subsp. cremoris grown with glycine in osmotically stabilized media. Appl Environ Microbiol 12, 3119-3123.

Kok, J., van der Vossen, J. M. B. M. \& Venema, G. (1984). Construction of plasmid cloning vectors for lactic streptococci which also replicate in B. subtilis and E. coli. Appl Environ Microbiol 48, 726-731.

Korch, C., Hagblom, P., Oehman, H., Goeransson, M. \& Normark, S. (1985). Cryptic plasmid of Neisseria gonorrbeae: complete nucleotide sequence and genetic organization. $J$ Bacteriol 163, 430-438.

Luchansky, J. B, Muriana, P. M. \& Klaenhammer, T. R. (1988). Application of electroporation for transfer of plasmid DNA to Lactobacillus, Lactococcus, Leuconostoc, Listeria, Pediococcus, Bacillus, Staphylococcus, Enterococcus and Propionibacterium. Mol Microbiol 2, 637-646.

Matteuzzi, D., Brigidi, P., Rossi, M. \& Di Gioia, D. (1990). Characterization and molecular cloning of Bifidobacterium longum cryptic plasmid pMB1. Lett Appl Microbiol 11, 220-223.

Messerotti, L. J., Radford, A. J. \& Hodgson, A. L. M. (1990). Nucleotide sequence of the replication region from the Mycobacterium-Escherichia coli shuttle vector pEP2. Gene 96, $147-148$

Missich, R., Sgorbati, B. \& LeBlanc, D. J. (1994). Transformation of Bifidobacterium longum with pRM2, a constructed Escherichia coli-B. longum shuttle vector. Plasmid 32, 208-211.

Mitsuoka, T. (1992). The human gastrointestinal tract. In The Lactic
Acid Bacteria; The Lactic Acid Bacteria in Health and Disease, pp. 69-114. Edited by B. J. B. Wood. London \& New York: Elsevier Applied Science.

Park, S. F. \& Stewart, G. S. A. B. (1990). High efficiency transformation of Listeria monocytogenes by electroporation of penicillin treated cells. Gene 94, 129-132.

Posno, M., Leer, R. J., van Luijk, N., van Giezen, M. J. F., Heuvelmans, P. T. H. M., Lokman, B. C. \& Pouwels, P. H. (1991). Incompatibility of Lactobacillus vectors with replicons derived from small cryptic Lactobacillus plasmids and segregational instability of the introduced vectors. Appl Environ Microbiol 57, 1822-1828.

Powell, I. B., Achen, M. G., Hillier, A. J. \& Davidson, B. E. (1988). Simple and rapid method for genetic transformation of lactic streptococci by electroporation. Appl Environ Microbiol 54, 655-660.

Ranes, M. G., Rauzier, J., Lagranderie, M., Gheorghiu, M. \& Gicquel, B. (1990). Functional analysis of pAL5000, a plasmid from Mycobacterium fortuitum: construction of a 'Mini' MycobacteriumEscherichia coli shuttle vector. J Bacteriol 172, 2793-2797.

Sambrook, J., Fritsch E. F. \& Maniatis, T. (1989). Molecular Cloning: a Laboratory Manual. Cold Spring Harbor, NY: Cold Spring Harbor Laboratory.

Sasaki, T., Asami, Y. \& Taketomo, N. (1987). Characterization and application of autoplasts of lactobacilli. FEMS Micobiol Rev 46, 59.

Scardovi, V. (1986). Genus Bifidobacterium. In Bergey's Manual of Systematic Bacteriology, vol. 2, pp. 1418-1434. Edited by P. H. A. Sneath, N. S. Mair, M. E. Sharpe \& J. G. Holt. Baltimore: Williams \& Wilkins.

Sgorbati, B., Scardovi, V. \& LeBlanc, D. J. (1982). Plasmids in the genus Bifidobacterium. J Gen Microbiol 128, 2121-2131.

Yasueda, H., Horii, T \& Itoh, T. (1989). Structure and functional organization of ColE2 and ColE3. Mol \& Gen Genet 215, 209-216.

Received 30 June 1995; revised 29 August 1995; accepted 6 September 1995. 